\title{
YTTRIA-STABILIZED ZIRCONIA SOLID OXIDE ELECTROLYTE FUEL CELLS MONOLITHIC SOLID OXIDE FUEL CELLS
}

QUARTERLY REPORT

JULY - SEPTEMBER 1989

88-61845(5)

Contract DE-AC21.88MC25166

Prepared for

U.S. Department of Energy

Morgantown Energy Technology Center Morgantown, WV
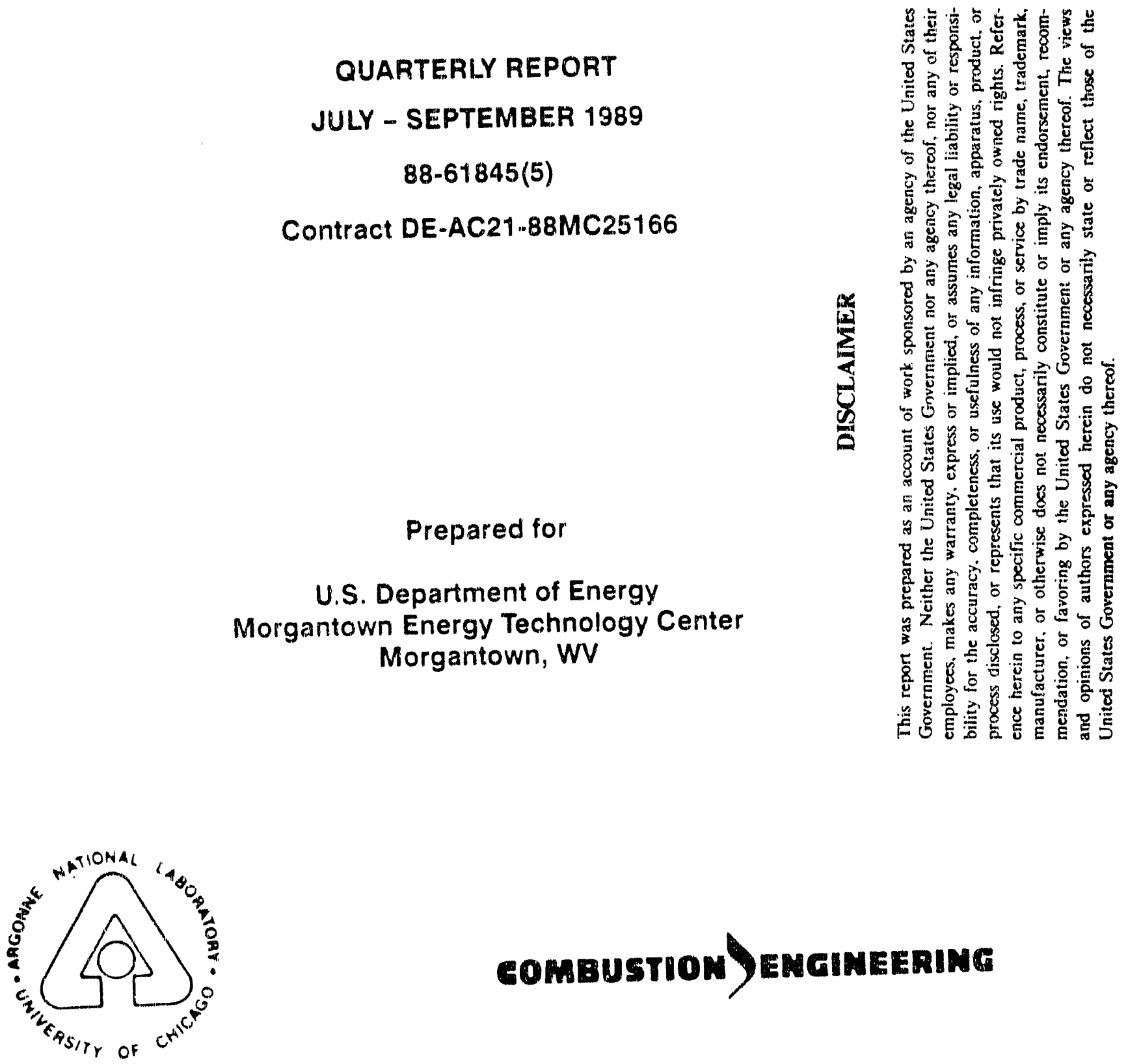

\section{GOMBUSTION GEMINEERING}

AiResearch Los Angeles Division

MASTER 


\section{INTRODUCTION}

This report describes the work performed on the U.S. Department of Energy (DOE)/Morgantown Energy Technology Center (METC) program, titled "Yttria-Stabilized Zirconia Solid Oxide Electrolyte Fuel Cells, Monolithic Solid Oxide Fuel Cells", during the period July through September 1989 (Contract DE-AC21-88MC25166). The program is conducted by the team consisting of Allied-Signal Aerospace Company, AiResearch Los Angeles Division (AiResearch). Argonne National Laboratory (ANL), and Combustion Engineering (CE). This program is part of the DOE program to identify advancements for fuel cells that offer significant improvements in performance, cost, and life over current goals. This program is focused on the monolithic design of solid oxide fuel cells. The specific objectives of this program are to:

(i) Assess the manufacturing costs for a monolithlic solid oxide fuel cell (MSOFC) and system costs for a coal-based MSOFC plant.

(ii) Modify electrode/electrolyte interfaces to improve the electrochemical performance of the MSOFC.

(iii) Test the performance of a MSOFC on simulated coal-derived fuels under specified test conditions. 


\section{BACKGROUND ON MONOLITHIC SOLID OXIDE FUEL CELLS}

The monolithic solid oxide fuel cell (MSOFC) is a recent design concept in fuel cell technology. The design employs thin ceramic layer components to form a compact, lightweight solid state structure. The MSOFC is composed of small cells bonded into a single structure much like a block of corrugated paperboard.

The key to this design is that the cells are very small ( 1 to $2 \mathrm{~mm}$ is the repeat distance from cell to cell) and the ceramic active components are also the structural cornponents of the cells. The monolithic design eliminates inactive structural support, increases active surface areas, and lowers voltage losses due to internal electrical resistance. The fuel cell thus has high efficiency, excellent performance, and high power density. Along with high efficiency and high power density, the MSOFC can also offer fuel flexibility, potential low-cost manufacturing, low operational and maintenance requirements, and environmental acceptability. The monolithic fuel cell can be inte rated with coal gasification plants and is expected to have high overall efficiency in the conversion of the chemical energy of coal to electrical energy.

In an MSOFC, fuel and oxidant produce a dc current by combining electrochemically across the solid oxide electrolyte at an operating temperature of $1000^{\circ} \mathrm{C}$. In the coflow version, the monolithic fuel cell consists of a honeycomb-like array of adjacent fuel and oxidant channels that resemble corrugated paperboard (Figure 2-1). Oxidant channels are lined with a porous cathode ( $\mathrm{Sr}$-doped $\mathrm{La} \mathrm{MnO}_{3}$ ), and fuel channels are lined with a porous anode $\left(\mathrm{Ni} / \mathrm{Y}_{2} \mathrm{O}_{3}\right.$-stabilized $\left.\mathrm{ZrO}_{2}\right)$. A gas-tight layer of electrolyte $\left(\mathrm{Y}_{2} \mathrm{O}_{3}\right.$-stabilized $\left.\mathrm{ZrO}_{2}\right)$ is located between the anode and cathode. An interconnect (doped $\mathrm{LaCrO}_{3}$ ), which is also gas-tight, connects the cells in electrical series. Typical thickness of the layers is 25 to 100 microns, and the distance from cell to cell is 1 to $2 \mathrm{~mm}$. As can be seen from Figure 2-1, the coflow MSOFC is made of two types of laminated structures, each composed of three ceramics - anode/electrolyte/cathode and anode/interconnect/cathode. The laminated structure containing the electrolyte is appropriately corrugated. The corrugations form the gas seals at the edges of the monolithic structure. Gas manifolding for the coflow MSOFC is complex, involving a transition section in which the oxidant flow is diverted to one side and the fuel flow to the other side of gas manifolds. In the crossflow version, the fuel and oxidant flow through channels formed by corrugated anode and cathode layers (Figure 2-2). The fuel and oxidant channels are at right angle to each other. The anode/electrolyte/cathode and anode/interconnect/cathode laminated structures are flat and stacked alternately between the corrugated anode and cathode layers. The crossflow version offers a simpler means of ducting gases in and out of the monolithic fuel cell. The crossflow design, however, results in a reduction in power density by a factor of about two below that of the coflow design.

Small cell size, thin ceramic components, and high operating temperature are the key features of the MSOFC. The small size of individual cells in the monolithic structure increases the active surface area. For example, an MSOFC with channels about $1 \mathrm{~mm}$ in diameter has a ratio of active surface area to volume of about $9.4 \mathrm{sq} \mathrm{cm} / \mathrm{cucm}$. This is about seven times the ratio for conventional fuel cells. On this basis alone, an MSOFC with a 


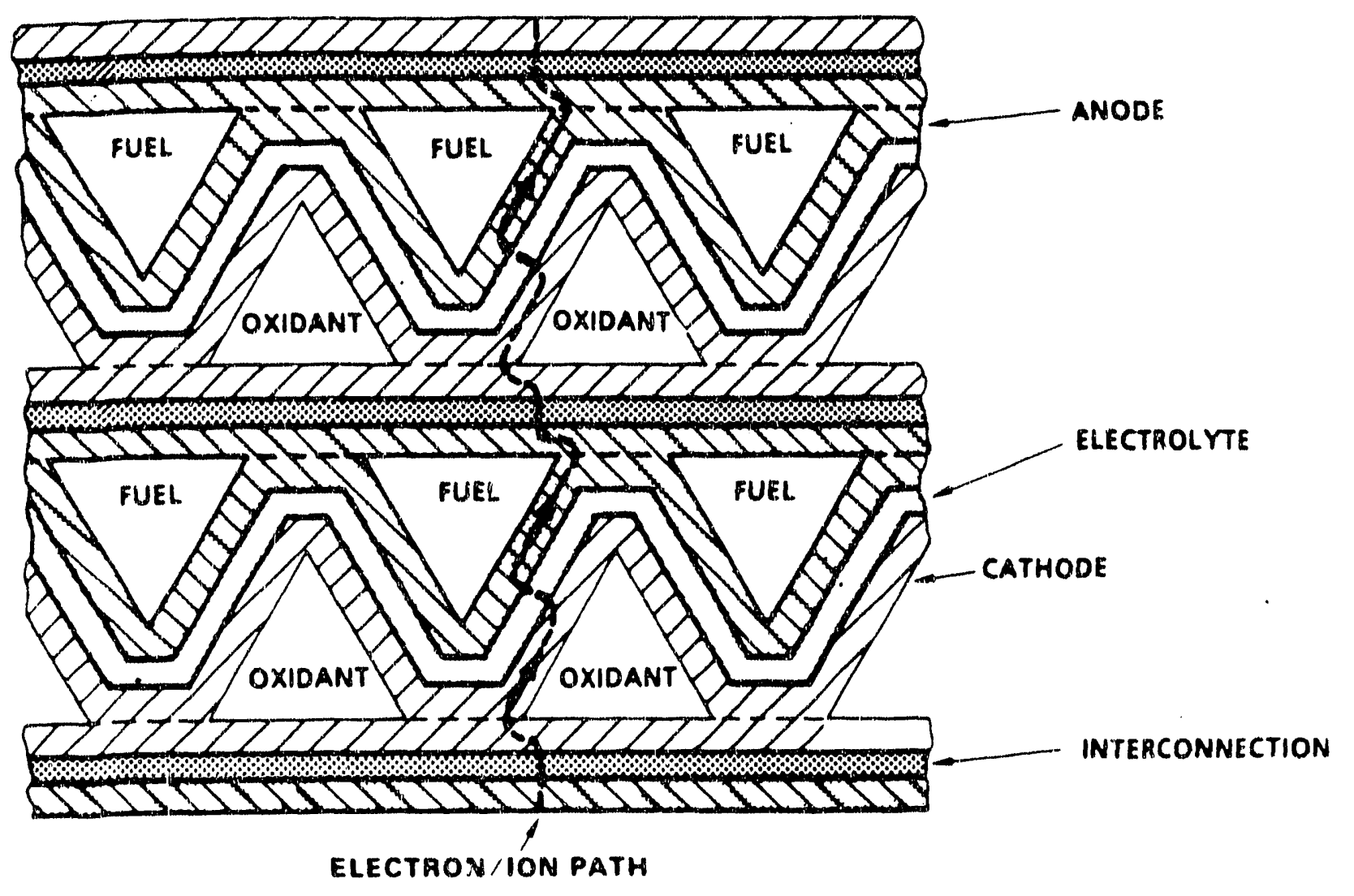

Figure 2-1. Coflow Monolithic Solid Oxide Fuel Cell 


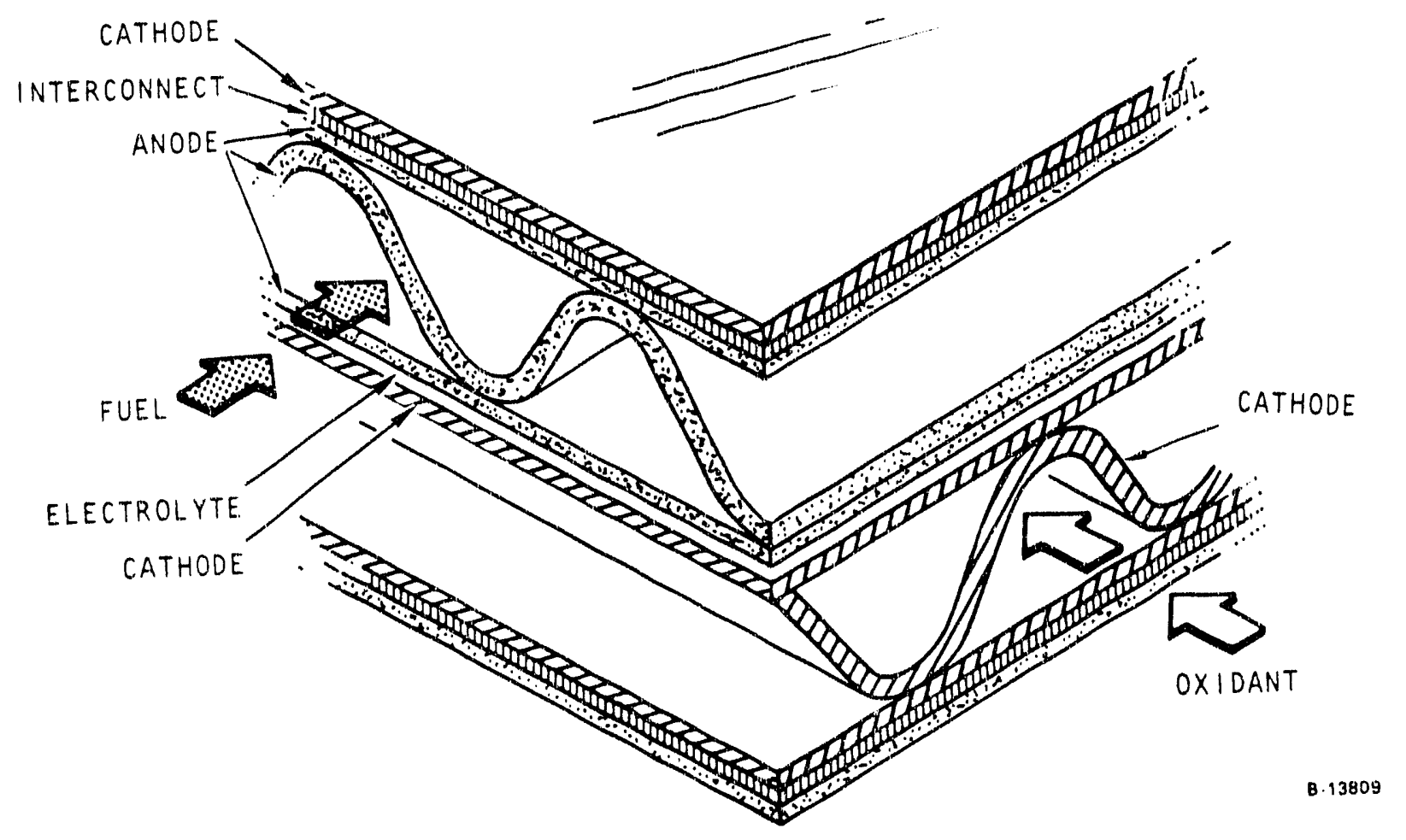

Figure 2-2. Crossflow Monolithic Solid Oxide Fuel Cell 
channel diameter of $1 \mathrm{~mm}$ should produce the same power as a conventional fuel cell seven times as large.

More importantly, the small cell size in the MSOFC reduces voltage losses due to internal electrical resistance. Because current is carried in-plane by the electrodes in both conventional and monolithic designs, a decrease in the cell size decreases the internal electrical resistance. In MSOFCs, the major source of internal voltage loss is the resistance that electrons encounter in the cell's ceramic components. Inside the operating fuel cell, an oxidation reaction (the electrochemical reaction of hydrogen fuel) releases electrons on the anode side of the barrier that separates oxygen channels from fuel channels. Flowing along the anode, electrons travel around the fuel channel wall and across the interconnection to the cathode of the adjoining oxygen channel (Figure 2-1). The electrons then flow along the cathode, around the oxygen channel to the cathode/elestrolyte interface, where they are consumed in a reaction (with oxygen) that produces an oxide ion. The oxide ion is transported through the plane of the electrolyte, reacts with hydrogen on the fuel side of the electrolyte to produce electrons, and the process continues. In this way, the electron current traverses the multicell monolithic structure. Because individual cells in the monolithic fuel cell are small, electron/ion paths are short and resistive losses are low. As a result of lower internal resistance, the MSOFC can be operated at higher current densities than conventional fuel cells while achieving the same output voltage.

The high current density of the MSOFC results from the small cell size and ensuing low internal resistance. The current density is high at the fuel inlet end of the fuel channel where the thermodynamic driving force (Nernst potential) is highest, as shown in Figure 2-3. Similarly, the current density is low at the outlet end of the fuel channel where the Nernst potential is lowest. The low current density at the fuel outlet is desirable because overall cell performance is determined by the voltage losses due to internfir resistance at the cell outiet. (Voltage losses arising from resistance to gas phase diffusion are negligible due to the thin electrodes.) Small resistance polarization losses ( 1 to $5 \mathrm{mV}$ ) at the fuel outlet mean that the fuel electrode, as an equipotential surface, approaches the maximum theoretical voltage set by thermodynamic conditions. The optimum cell performance is obtained when the average current density is increased to the point where resistance polarization losses at the fuel outlet just become significant, as shown in Figure 2-3. As a result, the cell nearly always operates within a percent or so of the maximum efficiency, even at high power output.

Because of the high operating temperature of the MSOFC $\left(1000^{\circ} \mathrm{C}\right)$, hydrou bon fuels can be reformed in the fuel channels. The reform reaction produces hydrogen which is consumied by the fuel cell, and this reform reaction is illustrated by

$$
\mathrm{CH}_{4}+\mathrm{H}_{2} \mathrm{O} \cdots>\mathrm{CO}+3 \mathrm{H}_{2}
$$

Catalytic reforming of methane and natural gas within a solid oxide fuel cell has been demonstrated. Reforming of higher weight hydrocarbons should proceed rapidly at the conditions of the MSOFC. 


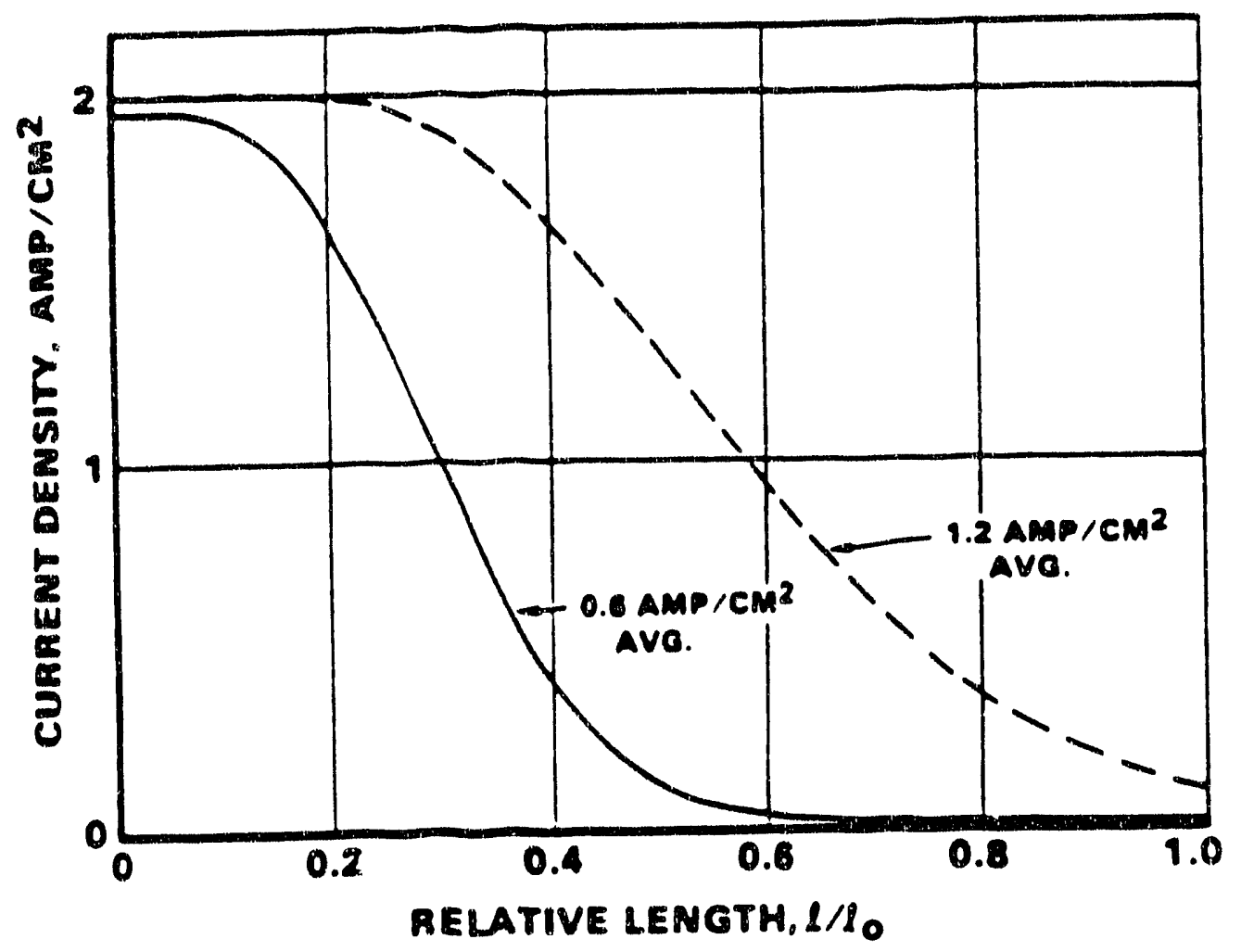

a 4 ass

Figure 2-3. Axial Current Distribution Along Fuel Channel (Fuel Enters at Relative Length of 0 and Exits at Relative Length of 1.0)

The MSOFC features of thin ceramic cornponents, small cell size, and $1000^{\circ} \mathrm{C}$ operating temperature combine to provide very high power densities of about $8 \mathrm{~kW} / \mathrm{kg}$ or 4 $\mathrm{kW} / \mathrm{L}$ for the MSOFC (fuel cell only, coflow version). This very high power density coupled with expected efficiencies of over 50 percent offers the possibility of successful competition with existing electrical generation systems. The ability of the MSOFC to reform hydrocarbon fuels within the fuel channels allows existing fuels and fuel distribution methods to be used with minor modifications for most applications. The fower density of the MSOFC is high enough to meet the demands of many diverse applicatior is such as aercspace, transportation, portable power systems, and micro-cogeneration systems, as well as more conventional utilities systems. The primary development challenge is to fabricate the MSOFC structure by co-sintering all four fuel cell materials into the corrugated "honeycomb" structure (stack). 


\section{COST STUDY}

\subsection{OBJECTIVE}

The objectives of the cost study are:

(i) To assess the manufacturing cost for the MSOFC assuming a nominal production rate of $200 \mathrm{MW} /$ year for coal-based system applications.

(ii) To define an integrated coal gasification MSOFC system with a potential for reducing plant heat rate and capital costs below $7,100 \mathrm{BTU} / \mathrm{kWh}$ and $\$ 1,300 / \mathrm{kW}$, respectively.

\subsection{MANUFACTURING COST STUDY}

Manufacturing cost calculations have been carried out for both crossflow and coflow MSOFC designs. Preliminary cost numbers obtained include direct costs (labor, plant maintenance, raw material costs, and utilities) and fixed costs (taxes and insurance and depreciation). These cost numbers are currently being reviewed and should be released to METC in the next several months.

\subsection{SYSTEMS STUDY}

In order to meet the objective for the systems study, below is a list of activities which will be performed.

1. Application

2. Site Requirements

3. Design Parameters

4. System Engineering Analysis

5. System Performance

6. Block Flow Diagram

7. Cost Estimate

8. . Preferred Plant Scheme

9. Report

Several of the above items have been initiated during this reporting period and are being reported on a preliminary basis.

\subsubsection{Application}

An objective is to assess solid oxide fuel cells for utility-scale power generation applications. A coal-fueled $200 \mathrm{MW}$ power plant was chosen as the application for study. 


\subsubsection{Site Requirements}

The reference plant location is assulned to be the Wisconsin-lllinois area in the West Central Region as defined in. Appendix B of the EPRI Technical Assessment Guide (tm). The site is assumed to be clear and level, with no special problems. The site is in Seismic Zone 1 at an elevation of 600 feet above mean sea level. A river for raw water supply is assumed to be in this region.

\subsubsection{Design Parameters}

\subsubsection{Plant Capacity}

The facility will be sized to produce 200 megawatts electric output. This capacity was chosen so that major plant cornponents could be both, shop fabricated and modular in construction. Such a design allows for close quality control during manufacture, reduced capital costs and short construction times. This size also allows utilities to add capacity in relatively small increments to match load growth more closely.

While nominal $200 \mathrm{MW}$ has been selected for the base case, electric output is not constant for all cases studied. Rather, the coal feed rate to the system is kept constant thus allowing plant output to vary depending on plant configuration and operating conditions.

\subsubsection{Reference Fuel Feed}

The facility shall be designed to process Illinois No. 6 coal which was selected because it represents a large coal reserve in this country and has relatively high sulfur and ash contents. Its performance in conventional power generations systems is well documented, and as a consequence, results from this study will be comparable to a wide variety of previously developed coal-based generating options.

\subsubsection{Plant Availability and Capacity Factor}

Coal-based MSOFC plants are expected to achieve high efficiencies and produce power at a cost of electricity competitive with alternate technologies. These characteristics and economic considerations indicate base loaded plant duty and high capacity factors which in turn, suggest that plant availability should be high. Therefore, plant availability of 95 percent and capacity factor of 80 percent were chosen.

\subsubsection{Plant Description}

A coal-fueled MSOFC power plant consists of the following sections:

- Coal Handling

- Oxidant Plant

- Gasifier

- Gas Clean-Up 


\section{- $\quad$ MSOFC Stack}

- Bottoming Cycle

- Utilities

A block flow diagram for a 200 MW MSOFC power plant is presented in Figure 3-1. This diagram is generic in that it is equally appropriate for any of the system pararneters being evaluated during the course of this study including choice of oxidant options, process conditions or power bottoming cycles.

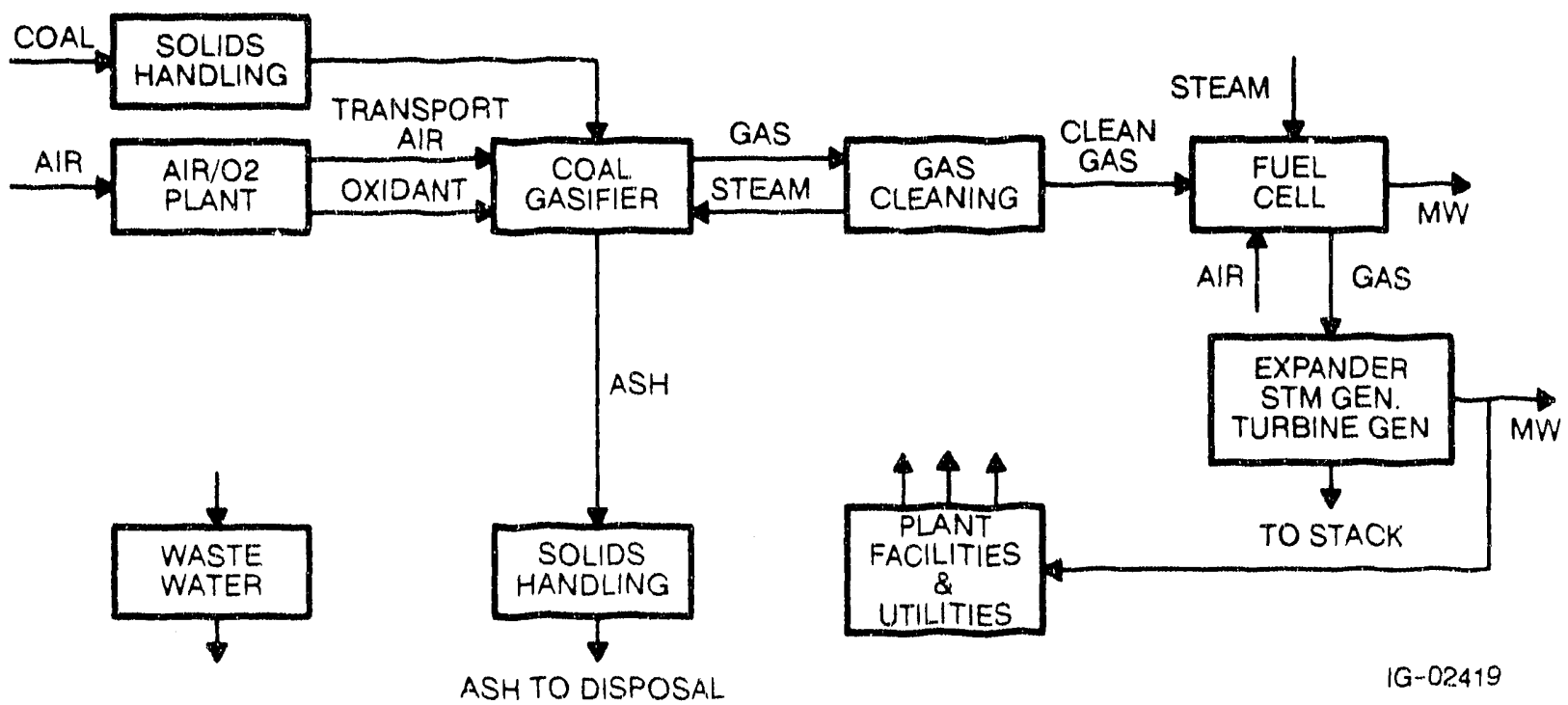

Figure 3-1. Preliminary Block Diagram for 200 MW Coal Fueled Monolithic Solid Oxide Fuel Cell Power Plant

From Figure 3-1 it can be seen that thie gasification section receives coal from the solids handling section. Coal is gasified with steam and air (or oxygen) from the oxidant plant, to produce a synthesis fuel gas stream. This section also provides transport gas to convey coal to the gasifier. Discharged solids from the coal gasifier, primarily ash with sulfated dolomite, pass to solids handling section before disposal.

Synthesis gas from the gasifier is purified in the gas cleaning section prior to being fed to the MSOFC section. Exhaust gas from fuel cells pass to a bottoming cycle section to recover heat energy and reduce pressure prior to being discharged to atmosphere through the outlet stack. The remaining plant sections include waste water treatment, general plant facilities and utilities. Discussion of individual sections is presented below.

\subsection{Coal Handling}

Run-of-mine coal is expected to be received at the plant site by rail. A unit train consisting of 100 ton capacity coal cars would be sufficient to service the facility for 
approximately one week. Coal is conveyed to live storage and stored in stockpiles by a bucket wheel stacker/reclaimer.

Reclaimed coal is conveyed to roll crushers. Coal from the roll crushers is conveyed to the coal drying and grinding units which produce minus one-quarter inch product. Moisture content of the coal shall be reduced to levels suitable for gasifier requirements. A pneumatic conveying system delivers the dried and ground coal to the gasifier feed system. All conveying and crushing systems are equipped with dust suppression systems.

\subsection{Oxidant Plant}

Design of this section depends upon the case definition since the study is to evaluate both oxygen and air-blown options. For $\mathrm{O}_{2}$-blown schemes, this section includes an air separating $\mathrm{O}_{2}$ facility to produce high purity oxygen required for both the gasification and gas cleaning sections, if required, (i.e., zinc ferrite options). The plant also provides nitrogen for transport gas, for blanketing (i.e., inerting gasifier lock hoppers), and for other uses in the plant. This section also produces cumpressed air for the sulfation steps in coal gasification.

The air separation facility will be sized to produce the tonnage of oxygen required for the specific case under analysis. The separation train shall consist of an air compressor, a cold box with a column/expander and an $\mathrm{O}_{2}$ compressor. Compressor intercoolers and aftercoolers shall be water cooled.

For air-blown gasifier schemes, this section consists simply of an air compressor station to provide process air where appropriate in the facility; for example, gasification, zinc ferrite regeneration, sulfation and transport gas.

\subsection{Fluidized Bed Coal Gasification}

Gasification technology is critical for development of an optimal MSOFC systems arrangement, and ultimately, for successful commercialization of coal-fueled fuel cell technology. Efforts are therefore currently underway by other contractors to compare technical and economic merits of the competing gasifier designs including fluid bed, entrained flow and moving bed gasifiers. While it is understood that such work is directed at molten carbonate fuel cell applications, the results have implications for solid oxide systems. Therefore, once this data is made available and can be integrated with results of this current work, a more detailed systems evaluation, one which takes account of an optimal gasifier design, can be undertaken.

A fluidized bed coal gasifier has been selected for this study so as to limit the number of possible design configurations, and facilitate evaluation of other key variables such as fuel cell performance, operating pressure and process conditions of down stream subsys. tems. Fluid bed technology was chosen because of its perceived relative high efficiency and modest capital costs. The two principal developers of fluidized-bed gasifiers are KRW and IGT. It is anticipated that performance data based on IGT technology will be utilized for this assessment. 
The fluid bed gasifier may be operated in either air-blown or oxygen-blown mode depending on the particular case definition. In concept, the system consists of a vertical, refractory lined carbon steel pressure vessel, with a conical grid and annular openings in the bottom at the apex of the cone. The vessel has multiple diameters with the largest diameter being that of the freeboard zone. During operation, ground coal mixed with steam and oxygen react within a gasifier to produce a hot synthesis fuel gas suitable for feeding to the fuel cell subsystem. A central opening in the gasifier vessel is for a steam $/ \mathrm{O}_{2}$ (or air) jet and a second annular ring is for ash discharge which runs counter-current to a secondary steam/oxidant inlet stream. The coal is quickly devolatized as it enters the hot fluidized bed and the resulting char forms the gasifier bed material. At the center of the gasifier, this char reacts with steam and oxidant which results in substochiometric combustion and the release of heat. Char further reacts with gaseous combustion products, i.e.: carbon dioxide and water vapor, to produce carbon monoxide and hydrogen. The heat released by these reactions is transferred vertically (and to a lesser extent horizontally) throughout the bed by the fluidized action of the bed. The product gas exits near the top of the vessel and contains fine particulates, most of which are collected in cyclones and recycled to the gasifier.

The addition of limestone to the gasifier results in several other reactions occurring in this zone, including calcination and sulfidation. The degree of sulfidation is determined by the reactor conditions, including temperature, pressure, calcium concentration of the bed, moisture level in the gas, and calcium/sulfur ratio in the feed.

\subsection{Gas Clean-up}

For this preliminary study, the gas cleaning options for gross capture of sulfur gases in the raw gas stream have been limited and will include only the hot DOE METC zinc ferrite system, coupled with a Nahcolite reactor system for removal of chlorides from coal-gas and a zinc oxide guard bed for removal of trace amount of sulfur to yield a gas that is satisfactory for feeding the MSOFC stack.

Regeneration gas from the zinc ferrite desulfurization is recycled to the gasifier - consisting primarily of dilute steam, and small amounts of sulfur dioxide. Significant nitrogen may be present in an air-blown system, but is nearly inconsequential in $\mathrm{a}_{2}$ blown system. The sulfur dioxide is removed from the gas and captured by the limestone, probably by a reaction path that involves reduction of the $\mathrm{SO}_{2}$ to $\mathrm{H}_{2} \mathrm{~S}$, followed by capture of the $\mathrm{H}_{2} \mathrm{~S}$.

Actual hot gas clean-up process details will depend upon the particular case definition.

\subsection{Monolithic Solid Oxide Fuel Cell Stack}

Clean gas from the gasifier, free of particulates and other contaminants such as $\mathrm{H}_{2} \mathrm{~S}$ and $\mathrm{HCl}$, enters the fuel cell system which consists of the following:

- MSOFC stack and inverter;

- Air compressor, recycle blowers, filters; 
- Heat recovery heat exchangers;

- Combustor;

- Piping and valves;

- Controls and safety systems.

Design bases for the fuel cell and fuel cell stack were selected to support definition of a practical fuel cell power plant section which would be attractive to the electrical utility industry. Logistical constraints for fuel cell stacks include a design which is modular, shop fabricated, easily assembled and which is able to withstand transport without breakage. A fuel cell ife expectancy of five years was selected for purposes of assessing technical issues and projecting maintenance costs of a fuel cell plant. Five years is comparable to that for state-of-the-art components of competing technologies and takes account of constraints such as densification of electiodes, maintenance of electrolyte conductivity, and the impact of thermal and mechanical stresses on physical properties of the ceramic componemts.

A major thrust of this work will be cirected towary investigating fuel cell system alternatives including:

- Fuel cell operating pressures

- Fuel utilization

- Bottoming power cycles

Various alternatives affect not only fuel cell performance but also the overall plant performance. Although fuel cell voltage decreases as the current density increases, total power per square foot usually increases. Thus, at higher current densities, stack size is generally decreased resulting in an overall lower cost of electricity.

Figure 3-2 shows a preliminary MSOFC power plant flow diagram in a steam bottoming cycle configuration. Clean gas from the hot gas cleari-up system enters the fuel cell where it is preheated betore entering the anode. Depleted anode exit gas is combusted with cathode exit air to provide heat for the bottoming cycle. Hot flue gas leaving the combustor section, is used to preheat the anode inlet gas in a fuel heater coil. The flue gas stream then passes through an air heater coil, gas expander, steam generator and waste heat boiler sections before being discharged through the stack. A pressure drop of 1 psi is generally assumed for the heat exchanger and fuel cell sections.

The reforming reaction is less important for coal-fueled MSOFC systems than for a natural gas-fueled systerns. Consequently, the process modeling undertaken here does not take account of methane reforming because of the expected low concentration (less than $2 \%$ ) of methane in the coal-derived fuel gas. Nevertheless, in an artual facility, maximum efficiency will be achieved with retorming, and therefore, the economic and technical trade-offs of internal versus external reforming in such systems will need to be investigated at a later stage. 


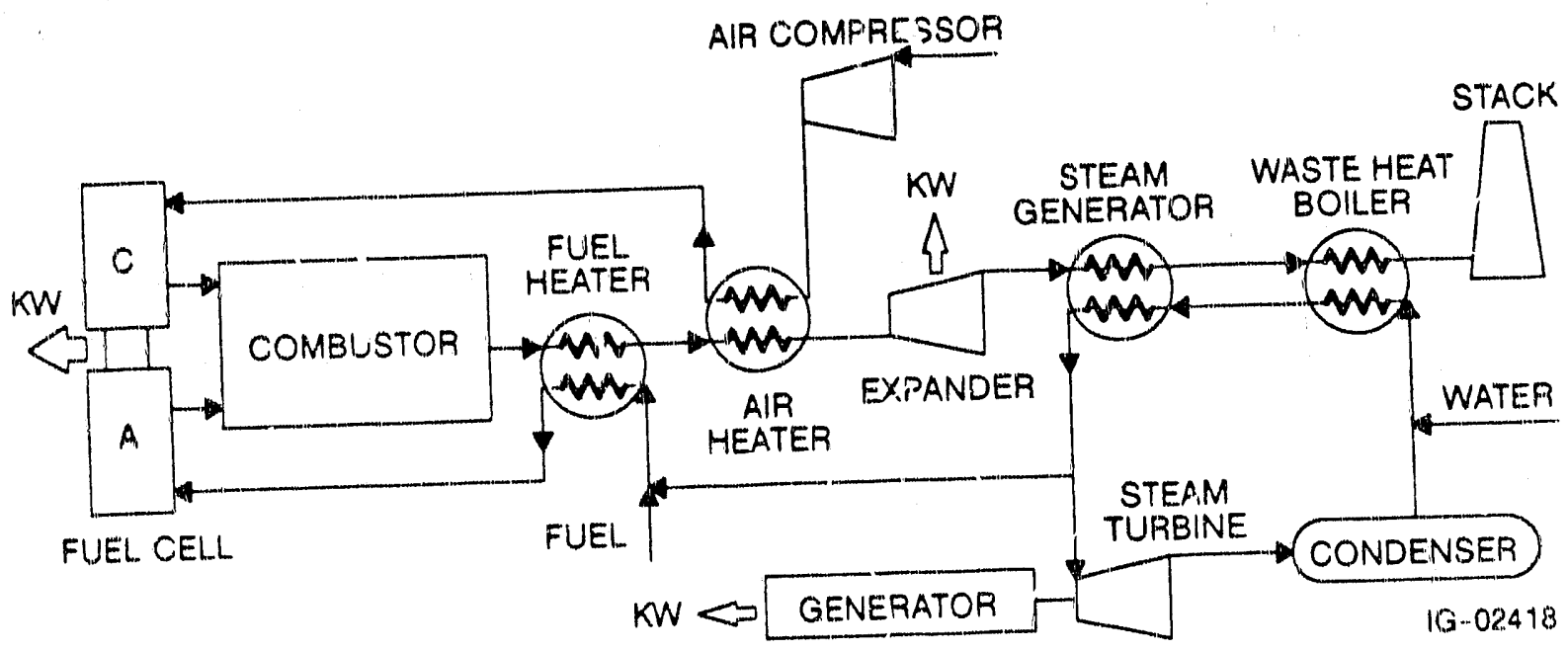

Figure 3-2. Preliminary riow Diagram for Monolithic Solid

Oxide Fuel Cell Power Plant

Fuel cell operation in combined cycle mode is very simila. to that in the steam bottoming cycle but is expected to include fewer heat exchangers and bloweis. In this cycle, the primary aim is to achieve highest gas temperatures entering the gas turbine. The air compressor may also be operated on a common shaft with the gas turbine.

\subsection{Bottoining Cycle}

Two power cycles will be considered: steam bottoming cycle and combined bottom ing cycle. For cases which incorporate steam bottoming, a typical utility steam cycle will be utilized in order to achieve high cycle efficiency.

Depending upon the steam bottoming scheme analyzed, superheated steam is to be generated in the fuel cell and gasification system while reheating is accomplished in the gasification section. Superheated steam is directed to a high pressure (HP) turbine to generate electric power. Steam discharged from the HP turbine is reheated in the gasification heat exchanger and is used in medium pressure (MP) reheat turbine to generate power. Stearn exiting MP turbine is directed to the lower pressure (LP) turbine for additional power generation. Steam leaving LP turbine is condensed in the condenser and is pumped to the deaerator and high temperature heaters for efficient use of heat available in the system. Steam required for gasification and gas clean-up catalyst regeneration is supplied by make-up water fed to condenser and through the deaerator. A pump circulates the water into heat exchangers located in the fuel cell flue gas stream to generate steam.

\subsection{Combined Cycle}

In combined cycle cases steam and 235 turbo-generators will be incorporated into the fuel cell system. Flue gas leaving the fuel cell section will be ducted to a high 
temperature gas turbine for power generation. The gas turbine will also power a compressor supplying air into the fuel cell. Flue gas leaving the gas turbine at moderate ternperature will enter a heat recovery steam generator to generate low pressure and temiperature steam which is expanded through a steam turbine, as well as supply process steam for gasification. The heat exchangers will include superheater, evaporator and economizer sections.

\subsection{Emissions}

Integration of a coal gasifier and fuel cell system ensures that emissions of atmospheric pollutants are minimill and will be less than established limits. This is because the gasifier gas is cleaned prior to introduction to the fuel cell stacks, and because the fuel cell is not a thermal combustion device. Utilization of cleaned fuel gas can be considered Best Available Control Technology (BACT). In addition, since the coal gas is not condensed, liquid waste treatment requirements are reduced.

\subsubsection{System Engineering Analysis}

Four alternative plant configurations will be evaluated during the course of this study. Variables affecting plant performance, efficiency and costs have been identified and are listed in Figure 3-3. The order in which these variables are to be evaluated during the study generally follow the fuel gas flow through major plant sections. Initially, gasifier oxidant, either oxygen or air. are to be assessed. Then fuel cell variables, including fuel utilizations are to be considered.

It was expected that plant efficiency and heat rates would be dependent on the bottoming cycle chosen for analysis. The bottoming cycles included here are a standard utility bottoming steam cycle, and a gas turbine combined cycle. 


\section{VARIABLES}

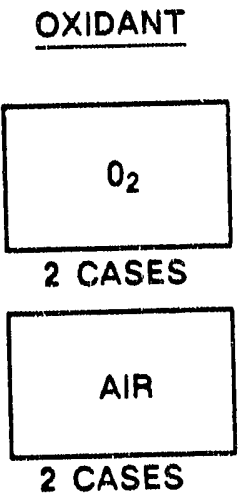

FUEL

UTILTZATION

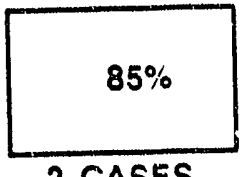

2 CASES

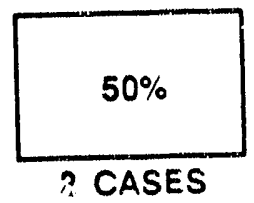

BOTTOMING CYCLE

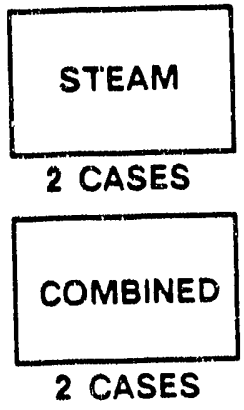

CONDITIONS

GASIFIER

OXIDANT

GAS CLEAN-UP

FLUID BED

FLUUID BED

FLUID BED

VARIABLE

HOT

O2/AIR

02/AIR

HOT

HOT

6 ATM

6 ATM

6 ATM

$85 / 50 \%$

VARIABLE

$85 / 50 \%$

STEAM/COMBINED

VARIABLE

IG-02420

Figure 3-3. System Engineering Matrix for the Monolith Solid Oxide Fuel Cell System Study 


\section{IMPROVE MSOFC ELECTROCHEMICAL PERFORMANCE (INTERFACIAL MODIFICATION)}

\subsection{OBJECTIVE}

The objective of the interfacial study is to modify electrodes and electrode/electrolyte interfaces of the MSOFC to improve its electrochemical performance. Specifically, characteristics of the electrode/electrolyte interfaces will be tailored to reduce interfacial resistance.

\subsection{INTERFACIAL MODIFICATIONS}

Lanthanum manganite powder produced by solid state reaction was used to modify the porosity of cathode and cathode-(lectrolyte intermediate layers in order to improve the electrical performance of cells. Also, the supply of catt sde-electrolyte intermediate tape was replenished.

Lanthanum manganite powder synthesized by solid state reaction was incorpurated into the cathode and cathode-electrolyte intermediate formulations (synthesis of this powder was discu ised in the last quarterly report, 88-61845(4), page 4-3). The morphology of the solid state reaction powder differs from that of the HUA Associates lanthanum manganite powder previously used in this program. The lower reactivity of the powder produced by solid state reaction should result in a more open electrode morphology, allowing greater mass transport. The solid state reaction powder was utilized in two different conditions: 1) sieved to eliminate large agglomerates, and 2) calcined, ground, and sieved to decrease the reactivity.

A single formulation of the cathode and the cathode portion of the cathode/electrolyte intermediate has been used throughout this program. This formulation contains a portion of as-received HUA Associates powder with a surface area of approximately $10 \mathrm{~m}^{2} / \mathrm{g}$. The reactivity of the remaining portion of HUA Associates powder in the formulation is decreased by calcining, grinding, and ball milling to reduce the surface area to approximately $1.5 \mathrm{~m}^{2} / \mathrm{g}$.

The effects of incorp rating lathanum manganite powder from the new HUA Associates lot and from the solid state reaction process were explored through a series of cathode and intermediate batches that were mixed in a torque rheometer. The torque rheometer is an instrument that contains a Banbury-style high intensity mixer but requires approximately one-fifth the batch volume as the Banbury mixer. The Banbury mixer was used to mix all previous batches for the program. The torque rheometer also allows improved control and monitoring of the mixing parameters. The constituents and characteristics of the batches made for this study along with those of previous cathode and intermediate batches used in the program are provided in Table 4-1. All of the data in this table was obtained from samples sintered at $1350^{\circ} \mathrm{C}$ for 0.5 hours. 
TABLE 4-1

\section{CHARACTERISTICS OF CATHODE (C) AND CATHODE ELECTROLYTE INTERMEDIATE (CE) BATCHES}

\begin{tabular}{|c|c|c|c|c|c|c|c|}
\hline \multirow{2}{*}{$\begin{array}{l}\text { Batch } \\
\text { Number }\end{array}$} & \multirow[b]{2}{*}{ Constituents } & \multirow{2}{*}{$\begin{array}{c}\text { Surface } \\
\text { Area } \\
\left(\mathrm{m}^{2} / \mathrm{g}\right)\end{array}$} & \multirow{2}{*}{$\begin{array}{c}\text { Percent } \\
\text { Theoretical } \\
\text { Density }\end{array}$} & \multicolumn{2}{|c|}{ Porosity } & \multicolumn{2}{|c|}{ Shrinkage } \\
\hline & & & & Total & Open & Diameter & Thicknass \\
\hline$C-0,238$ & Old HUA Associates, treated & 1.71 & 79.60 & $20.40 \%$ & $14.83 \%$ & $20.5 \%$ & $26.3 \%$ \\
\hline (Baseline) & Old HUA Associates, AR* & 11.09 & & & & & \\
\hline \multirow[t]{2}{*}{$C-08079$} & Old HUA Associates, treated & 0.86 & 74.89 & $25.11 \%$ & $24.19 \%$ & $20.5 \%$ & $25.2 \%$ \\
\hline & New HUA Associates, AR & 8.65 & & & & & \\
\hline \multirow[t]{2}{*}{ C. -08239} & Solid State Rx, uncalcined & 2.71 & 85.33 & $14.67 \%$ & $4.89 \%$ & $23.0 \%$ & $29.5 \%$ \\
\hline & New HUA Associates, AR & 8.65 & & & & & \\
\hline \multirow[t]{2}{*}{ C.08319 } & Solid State Rx, calcined & 0.19 & 67.22 & $32.77 \%$ & $30.97 \%$ & $19.5 \%$ & $20.3 \%$ \\
\hline & New HUA Associates, AR & 8.65 & & & & & \\
\hline \multirow[t]{4}{*}{ CE-08228 } & Old HUA Associates, treated & 1.71 & 77.96 & $22.03 \%$ & $10.74 \%$ & $20.5 \%$ & $26.9 \%$ \\
\hline & Old HUA Associates, AR & 11.09 & & & & & \\
\hline & Old TZ-8Y $\mathrm{ZrO}_{2}$, treated & 2.91 & & & & & \\
\hline & Old $\mathrm{TZ}^{-8 Y} \mathrm{ZrO}_{2}$, treated & 11.33 & & & & & \\
\hline CE-07269 & New HUA Associates, treated & 0.29 & 74.85 & $25.15 \%$ & $18.66 \%$ & $18.5 \%$ & $26.6 \%$ \\
\hline \multirow[t]{3}{*}{ (Baseline) } & New HUA Associates, AR & 8.65 & & & & & \\
\hline & New $\mathrm{TZ}-8 Y \mathrm{ZrO}_{2}$, treated & 4.69 & & & & & \\
\hline & New TZ-8Y Z $\mathrm{rO}_{2}$, treated & 12.59 & & & & & \\
\hline \multirow[t]{4}{*}{ CE-08189 } & Old HUA Associates, treated & 0.86 & 76.29 & $23.71 \%$ & $18.58 \%$ & $19.5 \%$ & $26.9 \%$ \\
\hline & Old HUA Associates, AR & 11.09 & & & & & \\
\hline & New TZ-8Y $\mathrm{ZrO}_{2}$, treated & 4.69 & & & & & \\
\hline & New TZ-8Y Z ZrO 2 , treated & 12.59 & & & & & \\
\hline \multirow[t]{4}{*}{ CE-09019-1 } & New HUA Associates, treated & 0.29 & 76.55 & $23.45 \%$ & $21.08 \%$ & $20.5 \%$ & $27.2 \%$ \\
\hline & New HUA Associates, AR & 8.65 & & & & & \\
\hline & New TZ-BY $\mathrm{ZrO}_{2}$, ireated & 4.69 & & & & & \\
\hline & New TZ-BY $\mathrm{ZrO}_{2}$, treated & 12.59 & & & & & \\
\hline \multirow[t]{4}{*}{ CE-09019-2 } & Solid State Rx, calcined & 0.19 & 78.27 & $21.73 \%$ & $16.88 \%$ & $21.0 \%$ & $26.4 \%$ \\
\hline & New HUA Associates, AR & 8.65 & & & & & \\
\hline & New TZ-8Y $\mathrm{ZrO}_{2}$, treated & 4.69 & & & & & \\
\hline & New TZ-8Y $\mathrm{ZrO}_{2}$, treated & 12.59 & & & & & \\
\hline
\end{tabular}

* as received

The first step of the study to increase the cathode porosity was to substitute the solid state reaction powder for the lower surface area HUA powder. Substitutions were made with both the uncalcined (C-08239) and calcined (C-08319) solid state reaction powders. As-received powder from the new HUA Associates lot was used for the high surface area 
with both the uncalcined (C-08239) and calcined (C-08319) solid state reaction powders. As-received powder from the new HUA Associates lot was used for the high surface area fraction in these batches. Because the baseline cathode batch, C-08238, was made with powder originating from the old HUA Assuciates lot, C-08079 was made with treated powder from the old lot and as-received powder from the new lot. C-08079 allows a comparison of batches containing the solid state reaction powders against the baseline cathode. As can be seen from Table 4-1 and the microstructure in Figure 4-1, the calcined solid state reaction powder used in C-08319 essentially doubled the open porosity present in the baseline cathode, although part of this effect is also attributable to the less reactive powder from the new HUA Associates lot. However, comparison of the open porosities of C-08079 and C-08319 shows that the calcined solid state reaction powder resulted in a more than $25 \%$ increase over the treated powder of the old HUA Associates lot.

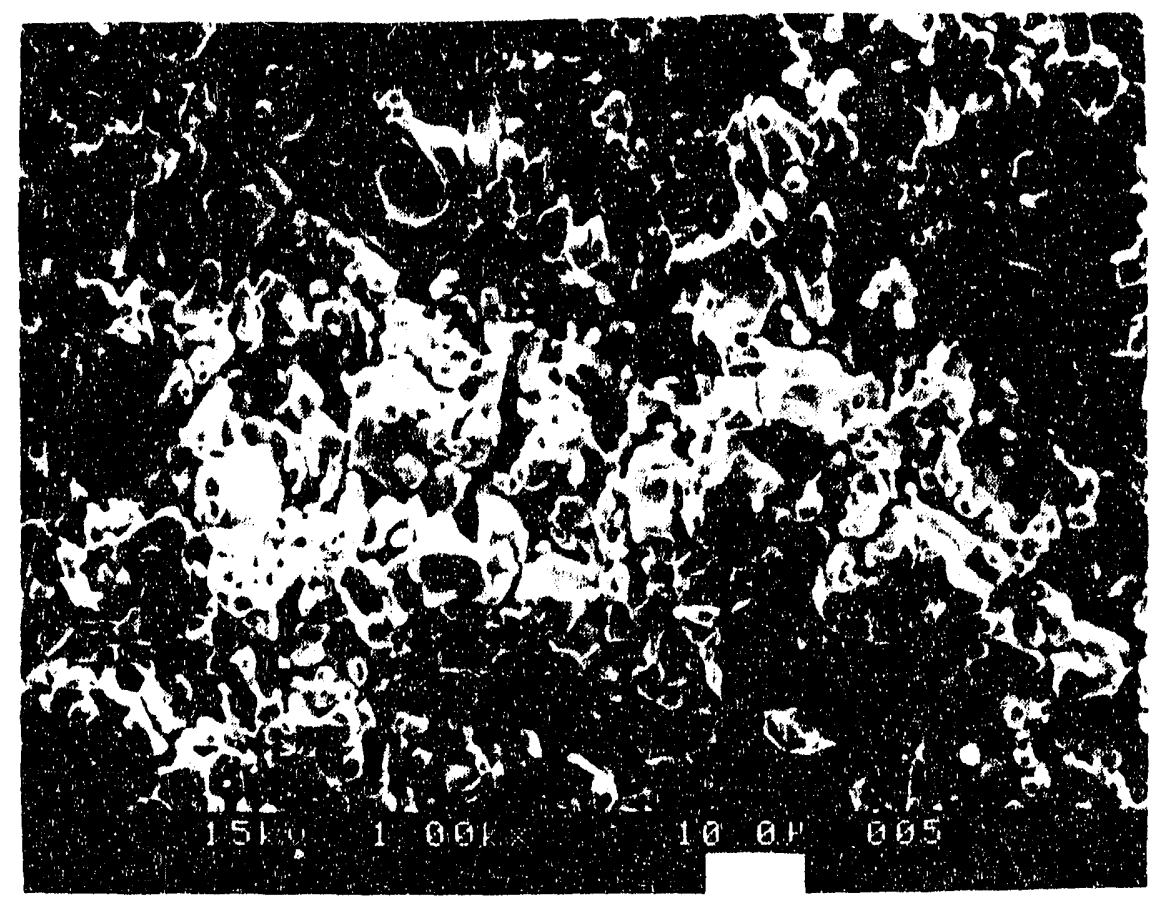

Figure 4-1. Porous Microstructure of Cathode C-08319 (1000x SEM, Sample 39-07)

The calcining treatment applied to the solid state reaction powder is necessary in order to obtain sufficient open porosity, as evidenced by the results for C-08239 and C-08319. The densities of these batches follow the expected trend from the surface area data, that is, the batches containing powders with lower surface area result in lower densities. The data in Table 4-1 also shows that the use of the new lot of HUA Associates powder or the calcined solid state reaction powder does not result in a significant change in the total shrinkage relative to that of the baseline batch (C-08238).

Another cathode batch consisting of treated and as-received powder from the riew HUA Associates lot would provide a direct comparison of the solid state reaction powder with the HUA Associates powder. Powder from the new HUA Associates lot will be treated so that this cathode batch can be made. 
The batch of cathode-electrolyte intermediate that has been used throughout this program (CE-08228) has been depleted, so a replacement intermediate batch (CE-07269) was made. The formulation of CE-07269 was the same as the baseline intermediate, CE-08228, but the lanthanum manganite and yttria-stabilized zirconia powders were from different lots of powders. In particular, the lanthanum manganite powder was considerably coarser than the previous lot. This change resulted in an increase in open porosity from 10.74 percent to 18.66 percent (refer to Table 4-1).

The improvement in cathode porosity lead to the incorporation of the calcined solid state reaction powder in cathode-electrolyte intermediate batches CE-09019-2, CE-08189, and CE-09019-1. CE-09019-1 was made to duplicate CE-07269 on the torque rheometer so that any difference between the two mixers (the rheometer and the Banbury) could be ascertained. Only a minimal difference was observed; therefore, it is concluded that mixing in the torque rheometer is comparable to mixing in the Banbury. Incorporating the calcined solid state reaction powder into the intermediate showed a decrease in open porosity as compared to batches containing treated HUA Associates powder from the old (CE-08189) and new (CE-09019-1) lots. This is contrary to what is expected when looking at the surface areas within the three lots, but powder surface morphology might be overriding this effect. Microscopic analysis of samples from these batches will be performed in order to substantiate the density results.

Tri-layer and four-layer single cells were fabricated from the combinations of tapes shown in Table 4-2. The anode and electrolyte layer used in the single cells have previously been characterized. Each of the new intermediate batches has been used within a trilayer cell series and also a four layer cell series utilizing the baseline cathode, C-08238. Likewise, each of the new cathode batches has been incorporated into a four layer single cell series with CE-07269. Also, a four layer cell series with a combination of CE-09019-1 and C-08319 (batches with the best measured open porosities) was made. All of the fired cells look to be in good condition upon visual inspection. A typical tri-layer single cell cross section is shown in Figure 4-2. Further processing studies are planned along with microstructural and chemical evaluation in order to more fully characterize the different electrode morphologies and their effect on cell performance.

\subsection{CHARACTERIZATION}

Three anode:electrolyte:anode composite samples, METC 16-18 and two C-787 composites made at ANL, were tested. The data from C-787-2 showed very low interfacial resistances, and it was concluded that these low resistances were due to a short circuit across the cell caused by some platinum paste that was used to attach the screens to the composite. Thus the data from C-787-2 were discarded. Both good cells showed similar changes in interfacial resistance as the partial pressure of $\mathrm{H}_{2} \mathrm{O}$ in the fuel was changed (Figure 4-3). At low $\mathrm{H}_{2} \mathrm{O}$ partial pressures, 0.001 atm, the interfacial resistance was $1.5 \mathrm{ohm}-\mathrm{cm}^{2}$. The interfacial resistance decreased with increasing $\mathrm{H}_{2} \mathrm{O}$ partial pressure to the lowest value of $0.1 \mathrm{ohm}-\mathrm{cm}^{2}$ at $0.03 \mathrm{~atm}$. Apparently, the availability of oxygen-bearing species at the electrolyte surface improves the charge-transfer kinetics and decreases the anode/electrolyte interfacial resistance. 
TABLE 4-2

COMPOSITION OF SINGLE CELLL SAMPLES FABRICATED FROM NEW CATHODE-ELECTROLYTE INTERMEDIATE AND CATHODE BATCHES

\begin{tabular}{|c|c|c|c|c|c|}
\hline & \multicolumn{4}{|c|}{ COMPOSITION } & \multirow[b]{2}{*}{ FUNCTION } \\
\hline & ANODE & ELECTROLYTE & INTERMEDIATE & CATHODE & \\
\hline \multirow[t]{8}{*}{ FOUR-LAYER } & A-06199 & $E-02149$ & CE-07269 & C.08079 & $\begin{array}{l}\text { EVALUATION/COMPARISON OF NEW } \\
\text { CATHODE BATCHES IN A 1:5:1:1 }\end{array}$ \\
\hline & A.06199 & $E-02149$ & CE-07269 & C-08239 & $\begin{array}{l}\text { EVALUATION/COMPARISON OF NEW } \\
\text { CATHODE BATCHES IN A 1:5:1:1 }\end{array}$ \\
\hline & A-06199 & $E-02149$ & CE-07269 & $C-08319$ & $\begin{array}{l}\text { EVALUATION/COMPARISON OF NEW } \\
\text { CATHODE BATCHES IN A 1:5:1:1 }\end{array}$ \\
\hline & A-06199 & $E-02149$ & CE-07269 & C-08238 & $\begin{array}{l}\text { EVALUATION/COMPARISON OF NEW } \\
\text { CATHODE BATCHES IN A } 1: 5: 1: 1 \& \\
\text { EVALUATION/COMPARISON OF NEW } \\
\text { INTERMEDIATE BATCHES IN A } 1: 5: 1: 1\end{array}$ \\
\hline & A-06199 & $E-02149$ & CE-08189 & $C-08238$ & $\begin{array}{l}\text { C-08238 EVALUATION/COMPARISON } \\
\text { OF NEW INTERMEDIATE BATCHES } \\
\text { IN A 1:5:1:1 }\end{array}$ \\
\hline & A-06199 & $E-02149$ & CE-09019-1 & C-08238 & $\begin{array}{l}\text { EVALUATION/COMPARISON OF NEW } \\
\text { INTERMEDIATE BATCHES IN A 1:5:1:1 }\end{array}$ \\
\hline & A-06199 & $E-02149$ & CE-09019-2 & C. -08238 & $\begin{array}{l}\text { EVALUATION/COMPARISON OF NEW } \\
\text { INTERMEDIATE BATCHES IN A 1:5:1:1 }\end{array}$ \\
\hline & A-06199 & $E-02149$ & CE-09019-1 & C. 08319 & $\begin{array}{l}\text { COMBINATION OF INTERMEDIATE } \\
\text { AND CATHODE WITH BEST OPEN } \\
\text { POROSITY INTO } 1: 5: 1: 1\end{array}$ \\
\hline \multirow[t]{4}{*}{ TRI-LAYER } & A-06199 & $E-02149$ & CE-07269 & None & $\begin{array}{l}\text { EVALUATION/COMPARISON OF NEW } \\
\text { INTERMEDIATE BATCHES IN A } 1: 5: 1\end{array}$ \\
\hline & A-C6199 & $E-02149$ & CE-08189 & None & $\begin{array}{l}\text { EVALUATION/COMPARISON OF NEW } \\
\text { INTERMEDIATE BATCHES IN A 1:5:1 }\end{array}$ \\
\hline & A.06199 & $E-02149$ & CE-09019-1 & None & $\begin{array}{l}\text { EVALUATION/COMPARISON OF NEW } \\
\text { INTERMEDIATE BATCHES IN A } 1: 5: 1\end{array}$ \\
\hline & A-06199 & E-02149 & CE-09019-2 & None & $\begin{array}{l}\text { EVALUATION/COMPARISON OF NEW } \\
\text { INTERMEDIATE BATCHES IN A 1:5:1 }\end{array}$ \\
\hline
\end{tabular}

There was a slight increase in interfacial resistance in the C-787-1 composite as the ratio of $\mathrm{He}$ to $\mathrm{H}_{2}$ increased (Figure 4-4). No increase in resistance was noticed for METC 16-18 in this case. The partial pressure of $\mathrm{H}_{2}$ apparently has little effect on the anode/ electrolyte interfacial resistance. The interfacial resistance seems to be affected more by oxygen-bearing species than by fuel molecules $\left(\mathrm{H}_{2}\right.$ or $\left.\mathrm{CO}\right)$.

Both METC 16-18 and C- 787 had similar curves for $\mathrm{CO} / \mathrm{CO}_{2}$ vs. interfacial resistance (Figure 4-5). The overall interfacial resistance of METC 16-18 was lower by, on average, $0.3 \mathrm{ohm}-\mathrm{cm}^{2}$. As in the case of the $\mathrm{H}_{2} / \mathrm{H}_{2} \mathrm{O}$ ratio, the interfacial resistance was reduced by increasing the $\mathrm{CO} / \mathrm{CO}_{2}$ ratio, but only up to a minimum. Relatively high interfacial resistance was observed $\left(0.3 \mathrm{ohm}-\mathrm{cm}^{2}\right)$ at a $\mathrm{CO} / \mathrm{CO}_{2}$ ratio of 0.1 , and this resistance decreased to the minimum value of $0.1 \mathrm{ohm}-\mathrm{cm}^{2}$ as the $\mathrm{CO} / \mathrm{CO}_{2}$ ratio increased to 1.0 . At higher 


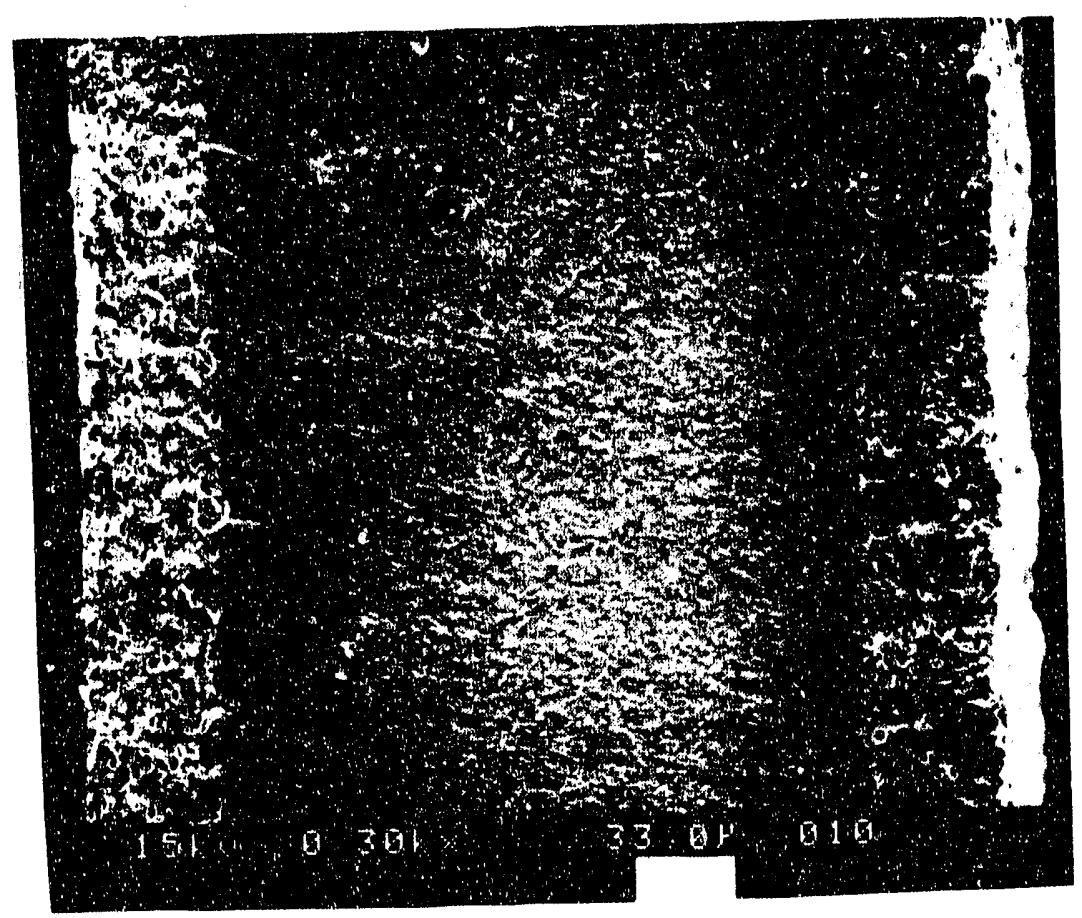

Figure 4-2. Cross Section of a Tri-Layer Single Cell (300x SEM, Sample 47-11)

$\mathrm{CO} / \mathrm{CO}_{2}$ ratios the resistance increased again, reaching a high of $0.7 \mathrm{ohm}-\mathrm{cm}^{2}$ at a $\mathrm{CO} / \mathrm{CO}_{2}$ ratio of 80 . A minimum probably exists in the $\mathrm{H}_{2} / \mathrm{H}_{2} \mathrm{O}$ system as well, but experimental difficulties have prevented good measurements at high $\mathrm{H}_{2} \mathrm{O}$ partial pressures. Precipitation of liquid $\mathrm{H}_{2} \mathrm{O}$ in the gas lines made the tests difficult. It is expected that the behavior of the $\mathrm{H}_{2} / \mathrm{H}_{2} \mathrm{O}$ system will be similar to that of the $\mathrm{CO} / \mathrm{CO}_{2}$ system.

A typical impedance curve for the anode:electrolyte:anode composite is shown in Figure 4-6. The anodes of METC 16-18 were similar in appearance to those of previous cells, although they were a little more porous than usual. The anode/electrolyte interfacial resistances observed in composite C-787-1 were typical of those observed in past cells fabricated at ANL. Typical anode/electrolyte interfacial resistances, as determined by AC impedance, have been between 0.09 and $0.33 \mathrm{ohm}-\mathrm{cm}^{2}$. Composite C-787-1 had a bulk resistance somewhat higher than can be attributed to the electrolyte layer (approximately $0.1 \mathrm{ohm}-\mathrm{cm}^{2}$ ). This indicates that some of the bulk resistance can be attributed to current distribution effects at one or both of the electrodes. The total area specific resistance of C-787 at $1000^{\circ} \mathrm{C}$ with $97 \% \mathrm{H}_{2}, 3 \% \mathrm{H}_{2} \mathrm{O}$ was $0.327 \mathrm{ohm}-\mathrm{cm}^{2}$.

\subsection{STACK FABRICATION}

Two different two-cell crossflow stacks, ST1038 and ST1039, which were reported in the last quarterly report (88-61845(4), pg. 4-12) have been processed. Figure 4-7 shows three different views of ST1039 after binder extraction. Delamination between the corrugated electrode layers has occurred, probably as a result of the mismatches in the shrinkage of the different layers. The shrinkage mismatch causes the anode corrugations to 


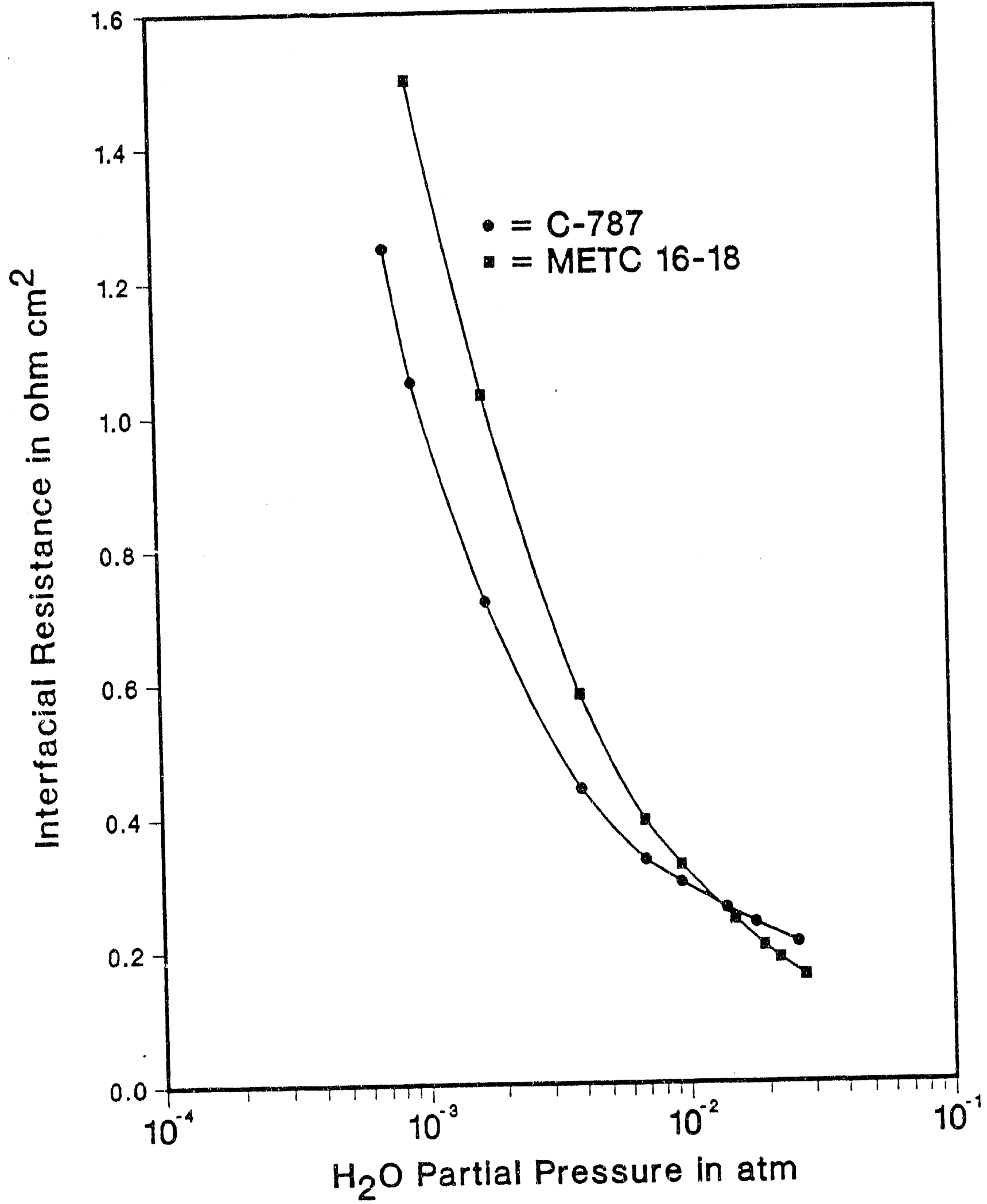

Figure 4-3. Interfacial Area Specific Resistance of METC 16-18 and C-787-1 Anode:Electrolyte:Anode Composites vs. Partial Pressure of Water 


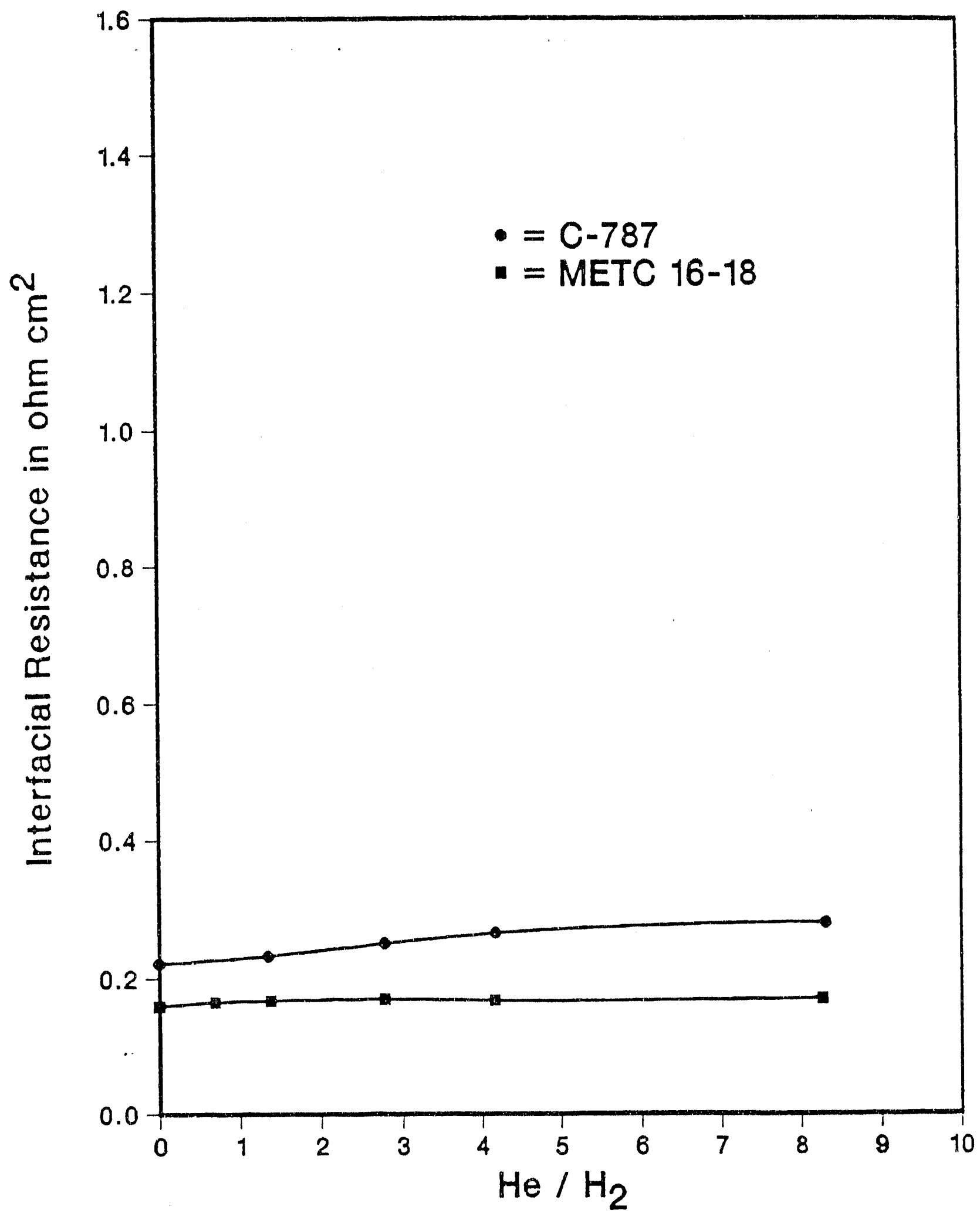

Figure 4-4. Interfacial Area Specific Resistance of METC 16-18 and C-787-1 Anode:Electrolyte:Anode Composites vs. Mole Fraction of Helium to Hydrogen 


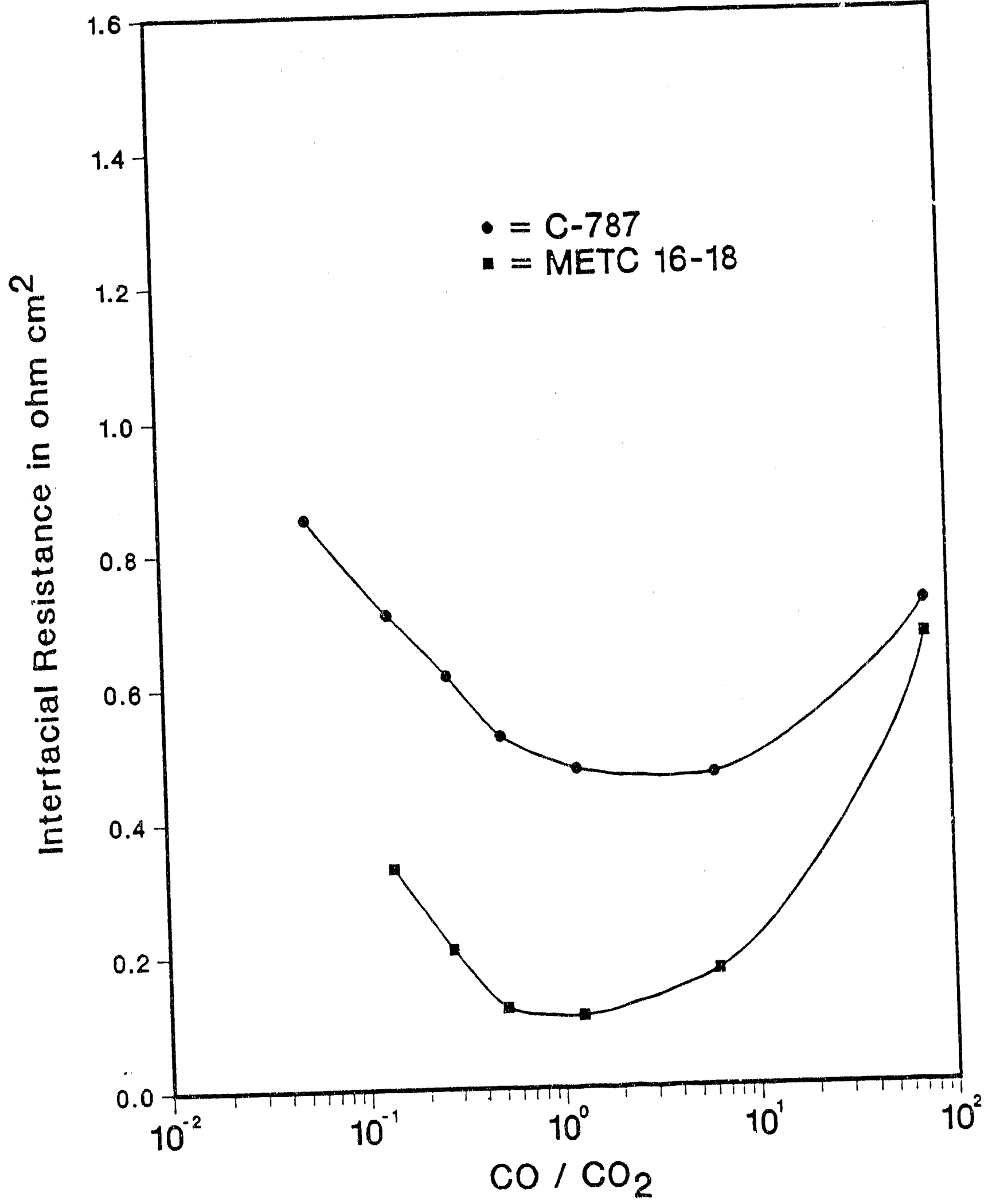

Figure 4-5. Interfarial Area Specific Resistance of METC 16-18 and C-787-1 Anode:Electrolyte:Anode Composite vs. Mole Fraction of Carbon Monoxide to Carbon Dioxide 


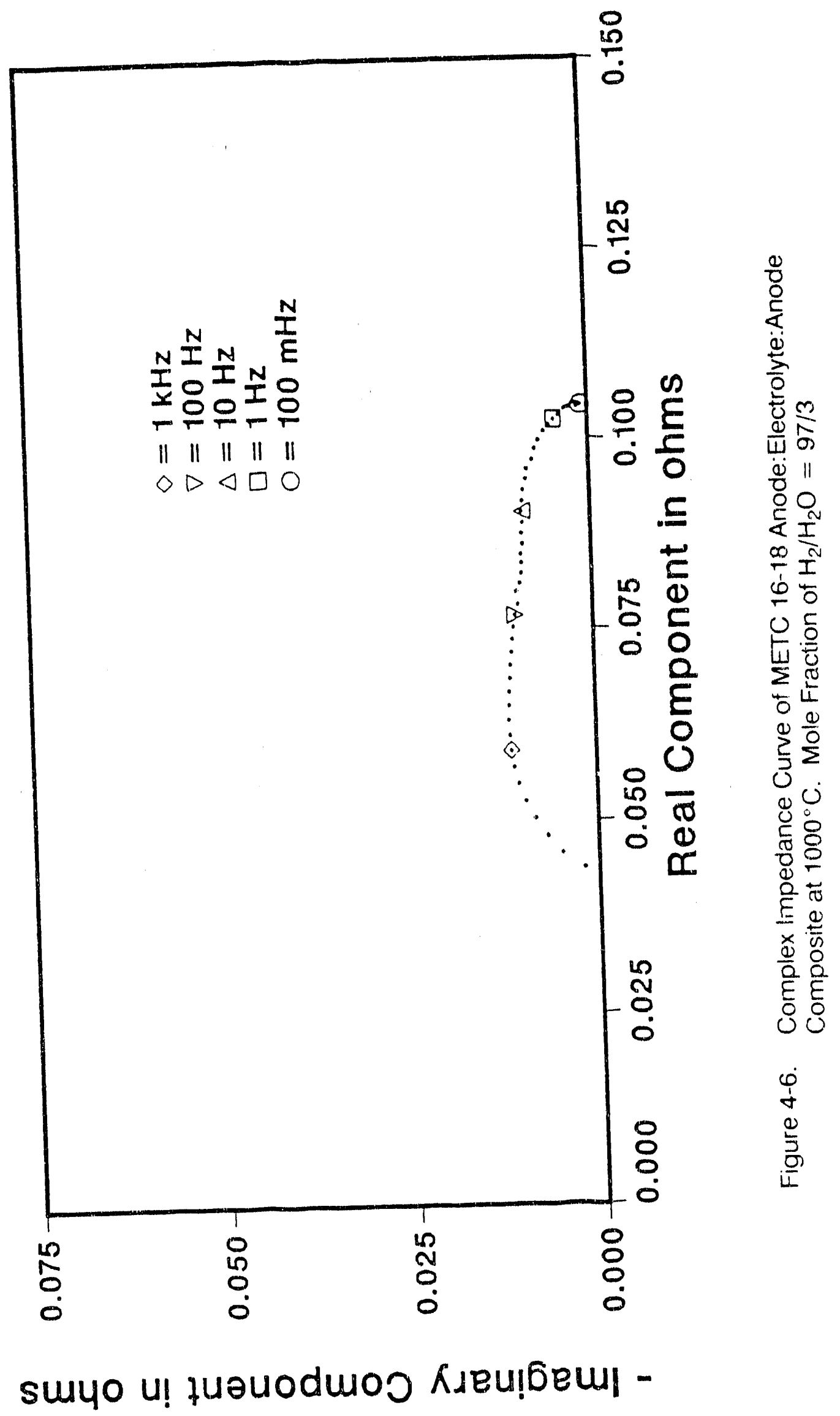



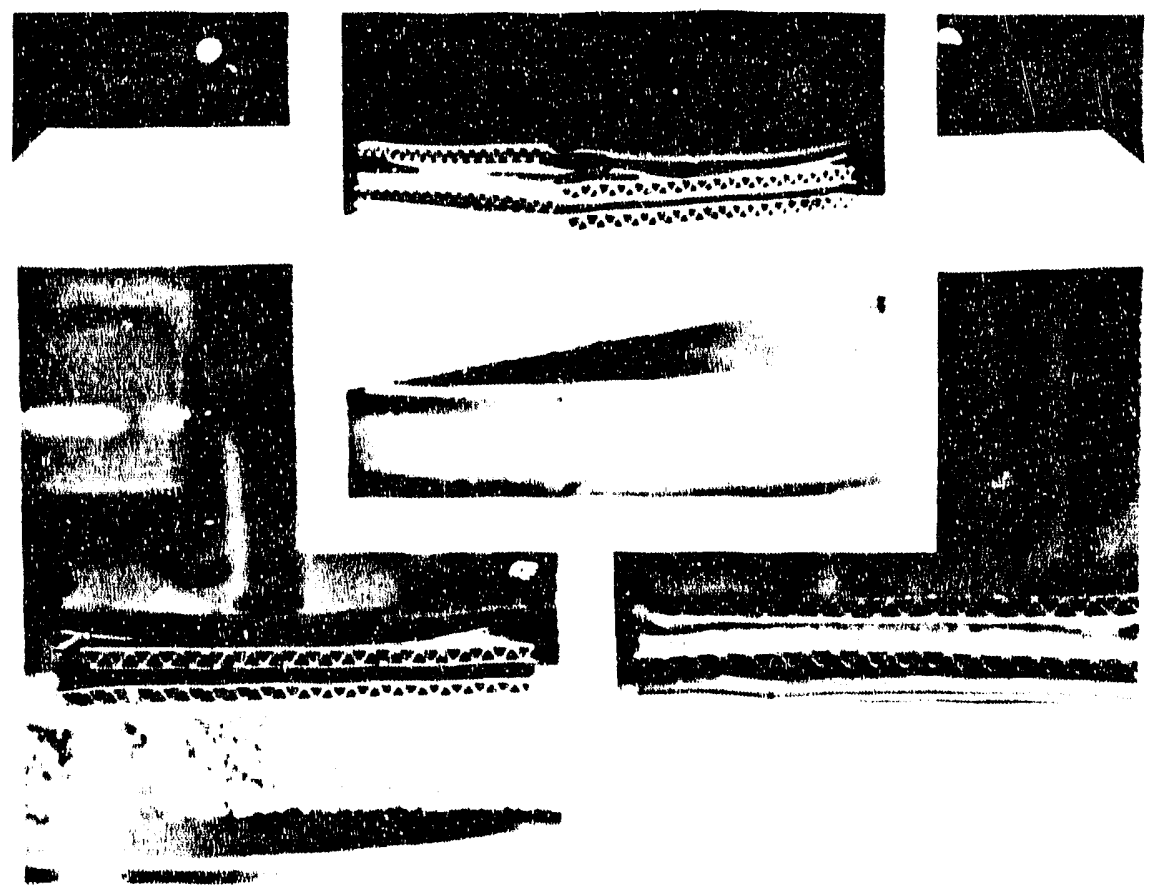

Figure 4-7. Three Views of ST1039 after Binder Extraction.

buckle more than cathode corrugations, and delamination from the flat tri-layers occurs. After sintering, the delamination is more severe and cracking within the corrugated electrode layers has occurred. The delamination and cracking have been attributed to two causes, mismatches in the shrinkage of the different layers and mismatch between the thermal expansion coefficients of the anode and interconnect.

Several single cell stacks consisting of corrugated electrode tapes bonded to each side of a singie cell flat sheet to form gas channels were fabricated and processed to assist in dere:mining the causp of the processing problems of ST1038 and ST1039. The corrugated layers of these stacks buckled similar to ST 1038 and ST 1039 during binder extraction, but the cracking and continued delamirlation observed in ST1038 and ST1039 after sintering did not occur. The single cell stacks did hold together despite the buckling.

In addition to fabricating single cells, shrinkage measurements were performed to assist in pinpointing the causes of the observed defects. The shrinkage dynamics of a composite tape (anode/ electrolyte/intermediate) as well as the individual layers were investigated. The resulting shrinkage curves are illustrated in Figure 4-8, which shows the shriniage due to both binder removal (low temperatures) and sintering (high temperatures). From these curves, it is evident that the anode layer has the greatest shrinkage during binder burnout. In addition, the effect of the anode shrinkage is evidenced in the bowing of the tape toward the anode side after firing, again indicating that the anode formulation has the grealest shrinkage. The low temperature composite shrinkage, however, is smaller than the anode because of the counteraction of the electrolyte layer. 


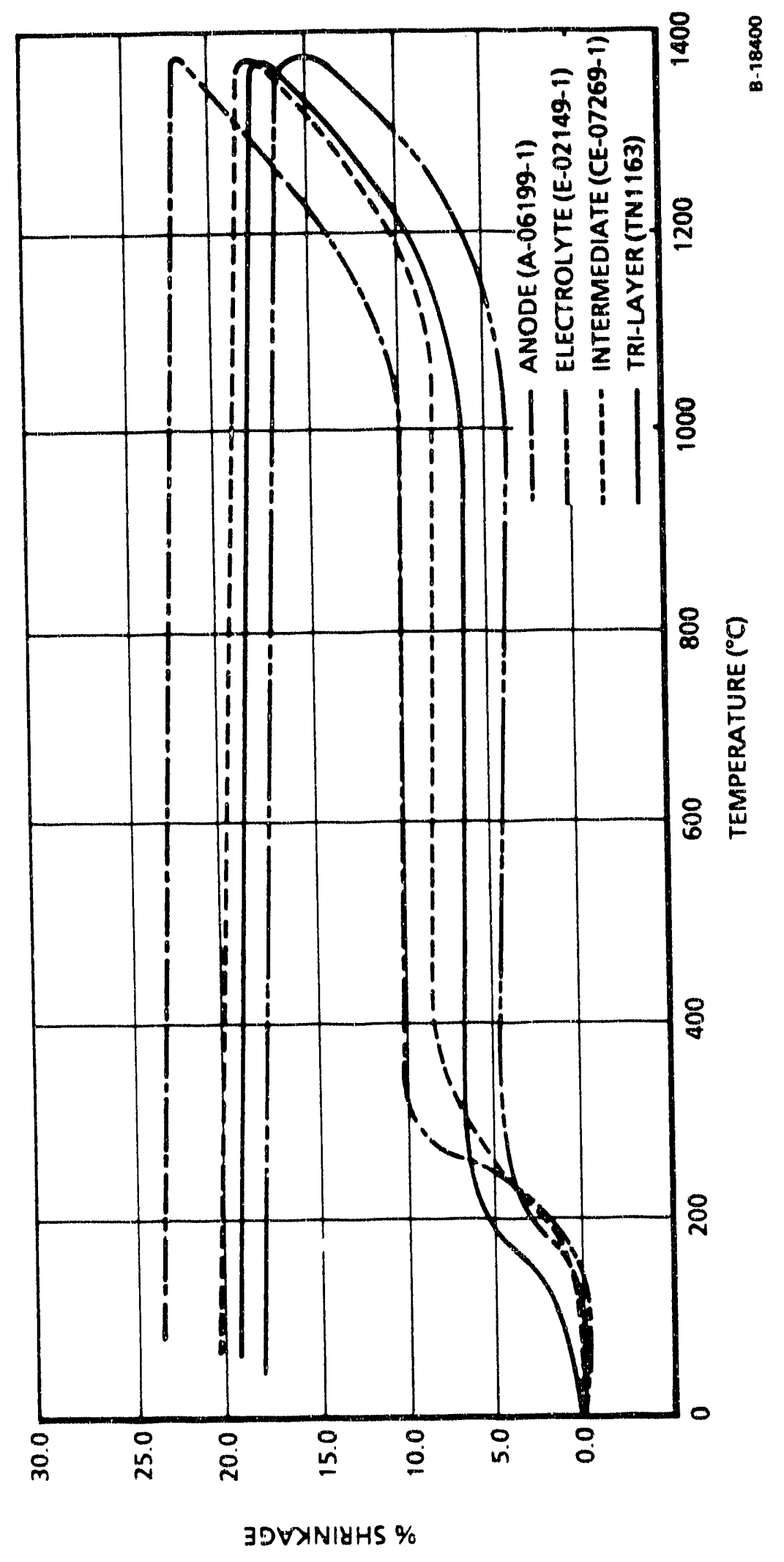

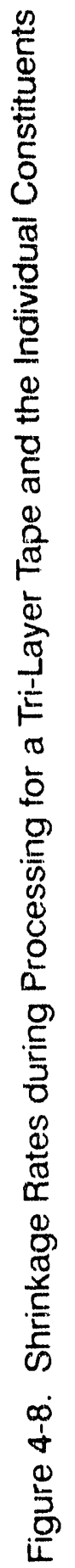


The sintering rate of the tri-layer composite tape reflects the closely matched rates of the three individual constituents; the major difference in the curves occurs during binder removal at low temperatures. The magnitude of the shrinkage from all layers during sintering is similar. This suggests that the processing conditions, and hence the surface area, of the oxide powders are consistent enough to provide a tape in which the layers sinter well together. The low temperature portion of the shrinkage curve, however, may be modified in order to minimize the differences between layers. The variation in the shrinkages of the individual tape layers in the composite tape is the predominant factor in attenuating the physical integrity of the samples during processing. In particular, the difference between the shrinkages of the anode and electrolyte layers is the largest, as observed in Figure 4-8, and may control the behavior of the tri-layer composite. One way to reduce the shrinkage differential in the composite tape is to increase the solids to binder ratio in the anode tape. A higher solids concentration in the anode tape would decrease the shrinkage upon binder burnout, but not significantly change the sintering portion of the curve. Another way to change the low temperature shrinkage is by decreasing the concentration of pore former in the tape, which would also eliminate some of the shrinkage.

In order to improve the shrinkage matching and minimize the buckling of the corrugated layers, several anode batches with formulation modifications will be made in the torque rheometer. Results from these batches will help us move toward successful processing of crossflow stacks. 


\section{PERFORMANCE ON COAL GAS}

\subsection{OBJECTIVE}

The objectives of this task are:

(i) To evaluate the performance of the MSOFC on simulated coal-derived gases.

(ii) To study the effect of sulfur contaminants on MSOFC performance, establish sulfur tolerance limit, and establish reversibility of sulfur contamination.

\subsection{PERFORMANCE TESTING}

No additional cells were tested during this reporting period. 

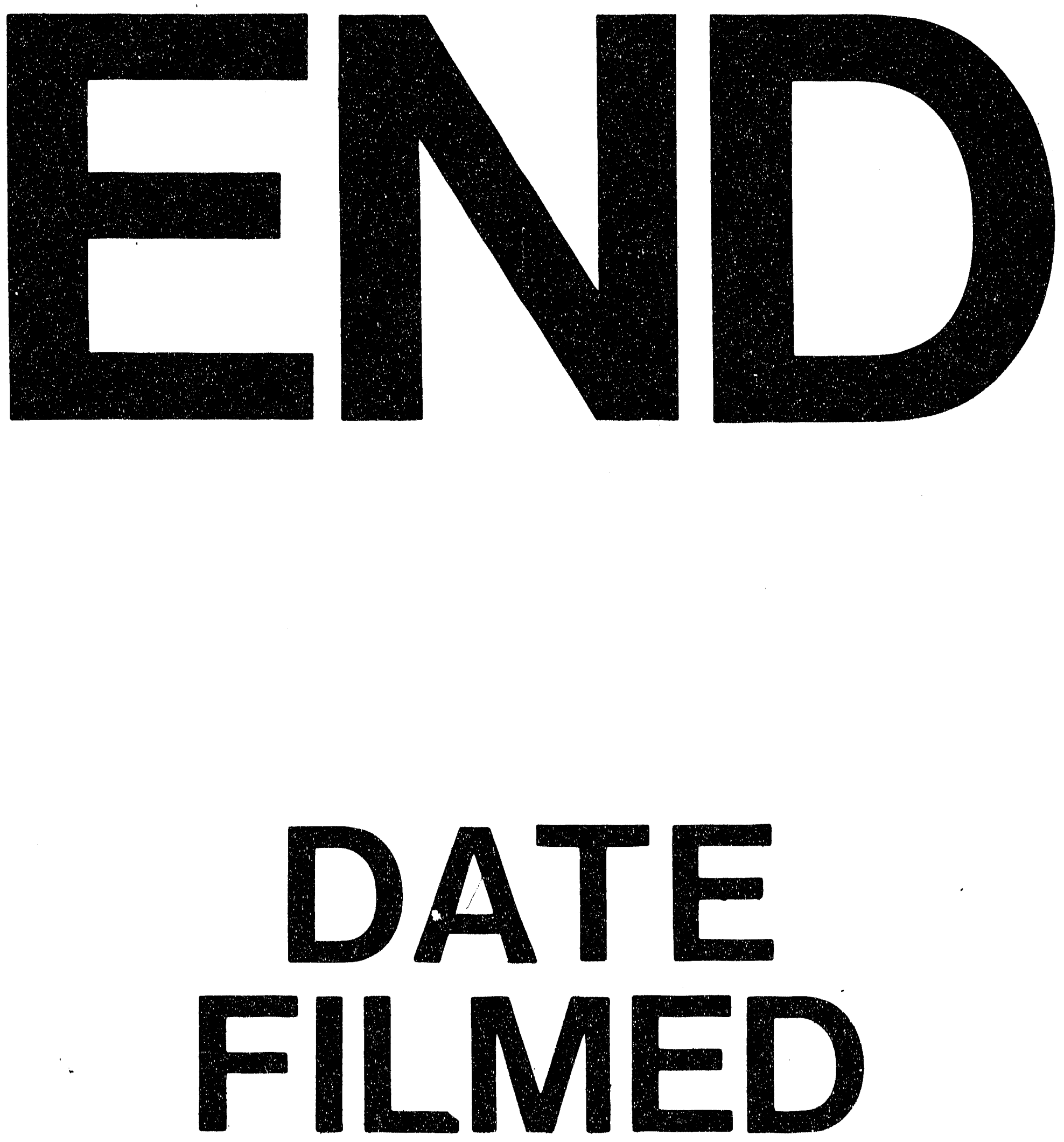

$\exists$

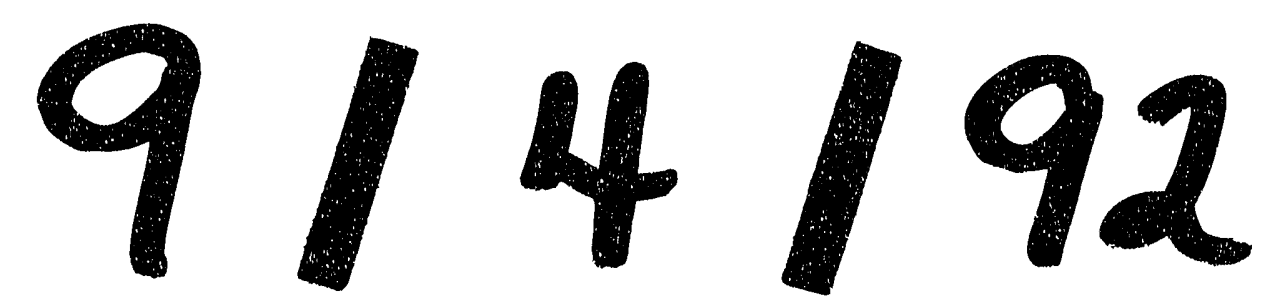


$\ldots \ldots \ldots$ 